\title{
El cine como encuentro y como distancia: Oiga vea, Cali: de película y Agarrando pueblo
}

\section{Álvaro Villegas ${ }^{2}$}

Recibido: 2014-12-11

Enviado a pares: 2014-12-15
Aprobado por pares: 2015-02-10

Aceptado: 2015-02-10

DOI: 10.5294/pacla.2015.18.3.4

Para citar este artículo / To reference this article / Para citar este artigo

Villegas, A. (septiembre de 2015). EL cine como encuentro y como distancia: Oiga vea, Cali: de película y agarrando pueblo. Palabra Clave, 18(3), 701-721. D0I: 10.5294/pacla.2015.18.3.4

\section{Resumen}

Este artículo reflexiona sobre tres películas dirigidas por los realizadores colombianos Luis Ospina y Carlos Mayolo entre 1972 y 1978. A través de la descripción de algunas secuencias, se plantea que en Oiga vea se construye una posición cinematográfica-marginal análoga a la posición popular-marginal; por su parte, Cali: de película se concentra en la forma en que los caleños crean cultura y comunidad a través de la desviación momentánea de los lugares propios de la institucionalidad, y, finalmente, en Agarrando pueblo se combate la sobreexposición de lo popular. A modo de conclusión, se señala que estas películas se constituyen en un espacio de encuentro de sensibilidades y sentidos que no está determinado de antemano.

\section{Palabras clave}

Colombia, cine, política, cultura de masas (Fuente: Tesauro de la Unesco).

1 Este artículo es resultado de la investigación Balance crítico del nuevo cine colombiano, 1963-1978. (Código Hermes 25617), financiada por la Universidad Nacional de Colombia.

2 Universidad Nacional de Colombia, Colombia. aavilleg@unal.edu.co 


\section{The Cinema as Meeting Place and as Distance: Oiga vea, Cali: de película and Agarrando pueblo}

\section{Abstract}

This article reflects on three films directed by Colombian filmmakers Luis Ospina and Carlos Mayolo between 1972 and 1978. Through the description of some sequences arises Oiga vea constructs an analogous marginalfilm position similar to the popular-marginal position; meanwhile, Cali: de película focuses on how Cali creates culture and community through the momentary departure from the sites of the institutions themselves, and finally in Agarrando pueblo combate the overexposure of the popular. In conclusion, it is noted that these films constitute a meeting of sensibilities and senses that are not predetermined.

\section{Keywords}

Colombia, cinema, politics, mass culture (Source: Unesco Thesaurus). 


\section{0 cinema como encontro e como distância: Oiga vea, Cali: de película e Agarrando Pueblo}

\section{Resumo}

Este artigo reflete sobre três filmes dirigidos pelos realizadores colombianos Luis Ospina e Carlos Mayolo entre 1972 e 1978. Por meio da descrição de algumas sequências, expõe-se que em Oiga vea constrói-se uma posição cinematográfico-marginal análoga à posição popular-marginal; por sua parte, Cali: de película concentra-se na forma como os caleños criam cultura $\mathrm{e}$ comunidade por meio do desvio momentâneo dos lugares próprios da institucionalidade e, finalmente, em Agarrando pueblo combate-se a superexposição do popular. Em conclusão, aponta-se que esses filmes constituem um espaço de encontro de sensibilidades e sentidos que não está determinado de antemão.

\section{Palavras-chave}

Colômbia, cinema, política, cultura de massas (Fonte: Tesauro da Unesco). 


\section{Introducción}

Las décadas de los sesenta y setenta trajeron consigo grandes transformaciones en el ámbito cinematográfico. En nuestro subcontinente, la aparición del nuevo cine latinoamericano (NCLA) retó las formas tradicionales de hacer y de pensar el cine, tanto en los países con cierta capacidad de producción industrial como en los países con una producción esporádica (León Frías, 2013). Para los cineastas generalmente agrupados bajo la categoría de NCLA era necesario combatir la cinematografía dominante como una forma específica de neocolonialismo cultural, a la par que se construía un cine propio que desvelara la realidad y fuera un instrumento de liberación. En este sentido, el subdesarrollo cinematográfico era inseparable del "atraso" social y económico.

Ortega y Martín (2003, p. 35) han señalado al respecto que la preocupación por el subdesarrollo fue una de las líneas de fuerza centrales dentro del documental latinoamericano entre las décadas de los cincuenta y setenta. Los documentales construyeron diversos modelos de representación visual y utilizaron múltiples estrategias retóricas para justificar las políticas desarrollistas gubernamentales o para criticarlas, al considerarlas producto de los intereses de las élites nacionales e internacionales.

Este artículo abordará tres documentales de Luis Ospina y Carlos Mayolo - Oiga vea, Cali: de película y Agarrando pueblo_, los cuales intervienen directamente en las discusiones sobre el desarrollo y el neocolonialismo cultural. Los documentales serán tratados como expresiones que realizan su trabajo crítico a partir de la ficción, la cual se entiende no como la construcción de un mundo-otro, sino como la posibilidad de creación de disenso (Rancière, 2010, p. 61). A partir de allí se analizarán las modalidades emergentes de circulación e intercambio de la palabra — entre la posición cinematográfica marginal y la posición popular-marginal - a la par de las diversas estrategias de exposición de lo visible, las cuales en su anudamiento hacen posibles, pero no necesarias, formas inéditas de acceso y de distribución de lo común por parte de los sujetos-cualquiera. 


\section{"Detrás de estas puertas quedan los distanciamientos, los antagonismos, las discrepancias, los egoísmos"}

Oiga vea (1972) es un mediometraje documental de 27 minutos, filmado en 16 milímetros y en blanco y negro. ${ }^{3}$ El documental está compuesto por tres grandes segmentos. En el primero se le presenta al espectador la ciudad de Cali y los VI Juegos Panamericanos, en el segundo se ingresa al barrio El Guabal y en el tercero se regresa a la Cali de los Juegos Panamericanos y se cierra con un plano rodado de nuevo en El Guabal.

Esta estructura fue construida en su totalidad durante el montaje, puesto que el rodaje no fue planificado de antemano y, por el contrario, se le caracterizó como una pesca imágenes (Navarro, 1977, p. 32). No obstante, para el espectador atento es claro que hay una línea conductora presente en el registro de las imágenes y de los sonidos; se trata de un punto de vista y de escucha que se podría denominar marginal, el cual es reforzado a través de la organización global de la película.

La dificultad de acceder a los escenarios deportivos, por carecer de los permisos oficiales, hace que los cineastas documenten los juegos desde el espacio público, donde se encuentran con "el pueblo". La exclusión de los sujetos y de los objetos técnicos no oficiales de la mayor parte de los espacios oficiales cerrados hace posible una perspectiva, como lo anotó lúcidamente Caicedo (1974), y, por supuesto, impide otras, que no obstante hacen parte del fuera de campo de Oiga vea, lo que da forma a una doble oposición entre lo oficial y lo popular, por un lado, y entre el cine oficial y el cine marginal, por el otro (Martínez Pardo, 1978, p. 286).

Al inicio de la primera secuencia, escuchamos la voz superpuesta del presidente Misael Pastrana Borrero: "Como presidente de Colombia no solo cumplo un deber, sino que experimento positivo orgullo al declarar inaugurados estos sextos Juegos Panamericanos". Este enunciado performativo se

3 Las tres películas sobre las que se reflexiona en este artículo pueden ser vistas en la cuenta oficial de Luis Ospina en Vimeo. Oiga vea está disponible en la siguiente dirección: http://vimeo.com/99744360 
escuchará una y otra vez, siempre fuera de campo. De esta forma, la voz que funda y hace posible los juegos, la voz autorizada para dar inicio al evento, es recluida en un espacio virtual que no será actualizado en toda la película.

La voz de Pastrana Borrero se alterna o se combina en ocasiones con música circense mientras se suceden y se contraponen imágenes de marchistas, ciclistas, vendedores ambulantes, jinetes, artistas callejeros, carros oficiales y cuatro planos filmados en El Guabal. El segundo de estos planos es de un hombre corriendo, y sucede al de un marchista en competencia; los dos últimos, que aparecen después de una competencia hípica, nos muestran niños jugando béisbol en una calle sin pavimentar que linda con un muro en el que se puede leer: "Vote por el Partido Comunista".

Poco después aparecen los créditos de la película, mientras se ve al Monumento a Cristo Rey bailar al son de "Pachito E'ché". Los créditos sirven para introducir una ciudad oficial bajo la tutela de la monumentalidad religiosa y las esculturas de Joaquín Cayzedo y Cuero, Sebastián de Belalcázar y Jorge Isaacs. Una ciudad, además, en la cual los caleños y, sobre todo, las caleñas pueden interactuar con los deportistas extranjeros y los ciudadanos ver las carreras ciclísticas en las calles. Pero de nuevo la confrontación visual emerge: a los ciclistas en competencia y a sus bicicletas se oponen las bicicletas de quienes los observan aparcadas en el suelo.

La contraposición entre el deporte oficial y el deporte popular es seguida por la confrontación al interior del deporte oficial con la victoria en béisbol de Cuba sobre Estados Unidos, la cual es aprovechada por Ospina y Mayolo para acercarse a los miembros del Instituto Cubano del Arte e Industria Cinematográficos (ICAIC) y preguntarles por su percepción sobre el triunfo. Luego de despedir a los miembros del ICAIC se realiza un corte y suena el himno nacional de los Estados Unidos, y a través de un tilt-up se pasa de la calcomanía de una pequeña bandera estadounidense, pegada en el vidrio de un carro, al techo donde se encuentra un camarógrafo, en cuya camiseta se lee en el plano siguiente: "cine oficial".

Es claro que los realizadores de la película están por fuera de la oficialidad y que, por ende, se encuentran en una posición de marginalidad ci- 
nematográfica no idéntica, pero sí análoga, a la posición popular-marginal. Desde esta posición interrogan a varias personas sobre el cine oficial. Se parte, como lo expresó Martínez Pardo (1978), de lo conocido y oficial para construir una nueva posición: marginal, cercana y empática a lo popular. Lo interesante y valioso es que no se hace a través de una voz superpuesta que comente y aclare el significado de las imágenes y la solidaridad que los cineastas e intelectuales les deben a los oprimidos; el sentido o, mejor aún, los sentidos deben ser reconstruidos por el espectador, quien debe asumir su propia posición frente a la contraposición de las imágenes entre sí y de estas con los sonidos: música, ruidos y palabras que la película le presenta. González ha planteado al respecto que "En entrevista Mayolo manifiesta dos preceptos casi religiosos presentes desde estas primeras incursiones [Monserrate y Una experiencia] en la dirección y edición cinematográfica: no recurrir al narrador en off para explicar la imagen, y no corresponder imagen y sonido para que así el espectador dimensione la imagen por deducción irónica" (2014, p. 149).

La última persona que responde a la pregunta sobre el cine oficial al final del primer segmento es quien empieza a hablar en el segundo: se trata de Jorge Eliécer Urbano, quien junto a su padre Alcides y a Luis Alfonso Londoño se convertirá en uno de los guías de los directores en su exploración del barrio El Guabal. A través de las entrevistas a los miembros de la familia Urbano y a Londoño, quien luego tendrá un rol protagónico en Agarrando pueblo, el barrio es definido como un lugar de "demasiada pobreza” y en permanente crisis por las inundaciones; en definitiva, un espacio abandonado a su suerte por el Estado y por el capital.

El discurso del desarrollo se convierte aquí en un marco explicativo válido e incuestionado. Al tiempo, este marco permite la confrontación entre una posición oficial y una posición popular-marginal. La primera acentúa el impulso al desarrollo urbano que traen los Juegos Panamericanos consigo, la segunda responde señalando la concentración de las obras y las inversiones en ciertas zonas, aunque no critica — por el contrario, deseala llegada del desarrollo. La centralidad de este segmento radica en que ya no se trata solamente de una analogía entre la posición del pueblo y la posición de los cineastas: ahora, al punto de vista y de escucha cercano, en 
sentido literal y metafórico, entre estas dos posiciones, se suma la voz popular-marginal. La utilización del sonido hace posible que los realizadores se encuentren "cara a cara" con los otros, cuya voz permite que el documental cobre una dimensión interactiva, acusadora y provocadora. Si bien se trata de un discurso argumentativo y expositivo, no es un monólogo rígido sino una elaboración cuya condición de posibilidad es su dimensión dialógica, el encuentro entre las posiciones sociales y los lenguajes análogos pero diferentes de los habitantes de El Guabal y los cineastas.

El tercer segmento comienza con un zoom out del salto de un clavadista, que en un primer momento parece filmado desde adentro del escenario deportivo, pero que luego se descubre que fue filmado desde afuera, al lado de un grupo de espectadores que pueden ver el principio de los saltos pero nunca su final, porque una pared se interpone en su visión. De esta forma, el zoom out traduce visualmente un posicionamiento ético en el cual el artificio cinematográfico se utiliza para revelar la ambigüedad de lo real y la centralidad de los puntos de vista. Esta imagen es sucedida por un zoom in detrás de una malla de una competencia de golf y otros planos de numerosas personas que intentan ver los juegos agolpadas detrás de más mallas y de las vitrinas de los almacenes que exhiben televisores; estas imágenes están en contrapunto de nuevo con la voz superpuesta del presidente de la República, que señala: "Detrás de estas puertas quedan los distanciamientos, los antagonismos, las discrepancias, los egoísmos, aquí solo hay campo y espacio para la generosidad". La contradicción entre el discurso oficial de generosidad interclasista y la exclusión del "pueblo" de los juegos se refuerza luego con la voz en off de Alcides Urbano, quien, mientras se muestran los precios de las entradas a los escenarios deportivos, cuenta que los pobladores de los barrios pobres de Cali no tienen dinero para pagarlos, a lo que se suma que el evento se realizó en medio de numerosos conflictos sociales.

El recorrido realizado por los cineastas e impulsado por las palabras y las acciones de los habitantes de El Guabal desnaturaliza el orden policial de los juegos. Este orden no está impuesto exclusivamente por los jóvenes miembros de la policía militar que Mayolo y Ospina hacen bailar al ritmo de "El Corneta" de La Sonora Matancera; el orden policial es una 
“[... ] lógica de los cuerpos en su lugar en una distribución de lo común y de lo privado, que es también una distribución de lo visible y lo invisible, de la palabra y del ruido" (Rancière, 2010, p. 62).

Desde esta misma perspectiva, el disenso es inmanente a la política, en tanto esta implica la ruptura de las competencias y los espacios dados $a$ priori; la política emerge solo en tanto los cuerpos acceden, o aunque sea lo intentan, a las posiciones y a las posibilidades a las que no deberían acceder según la policía. Cuerpos - como los de familia Urbano- que hablan, cuando no deberían hacerlo o sobre lo que no les correspondería hablar, cuerpos que ven a otros cuerpos que no deberían ver mientras no paguen por ello. En este sentido, "La política es la actividad que reconfigura los marcos sensibles en el seno de los cuales se definen objetos comunes" (Rancière, 2010, p. 61). En Oiga vea, el espectador se ve confrontado con el ejercicio político de los cineastas y del "pueblo", pero sobre todo con el encuentro de ambos: es a través de ese encuentro que se potencian nuevas formas de mirar y de posicionarse que retan el orden policial.

Esto no quiere decir que el "pueblo" tenga una voz unificada, ni siquiera que este término sea completamente adecuado — aunque puede ser el menos inadecuado-; su uso en este artículo está dado justamente por su polisemia y por su carácter conflictivo. El encuentro entre "pueblo" y cineastas dista de ser inocente: además de la selección de qué se incluye en el montaje final dentro de todo lo registrado en el rodaje, también se debe tener en cuenta la selección misma de los entrevistados, que resulta más notoria en el segmento de El Guabal, en el cual básicamente escuchamos a cuatro personas: Jorge Eliécer y Alcides Urbano, Luis Alfonso Londoño y un niño. La voz -oficial- de un agente de policía, reducida a unas pocas palabras, será rápidamente contradicha, al igual que la voz superpuesta del presidente de la República, que recibirá el mismo tratamiento en los otros segmentos. Los cineastas toman claramente partido por las voces críticas de los sextos Juegos Panamericanos y prácticamente silencian a las voces oficiales. La película finaliza contraponiendo dos escenas: en un primer momento se muestra a un par de obreros que pintan una valla donde se invita al "pueblo caleño" a pagar cumplidamente sus impuestos para garantizar 
el progreso de su ciudad luego de los juegos; después se regresa a El Guabal, en donde los espectadores se ven confrontados con una sonrisa marginal — alejada radicalmente de los estereotipos de belleza y salud dental—, mientras una música circense se ralentiza. No hay duda de que el espectáculo concluyó: los espacios excluidos, la sonrisa excluida o, mejor aún, la sonrisa como sinécdoque de la exclusión cierra la película.

\section{"Pero el diablo estaba adentro y no ha podido salir"}

Cali: de película (1973) es un documental de 14 minutos, filmado en formato de 35 milímetros y a color. ${ }^{4}$ Es posible identificar en él diez secuencias: 1) vistas de Cali, 2) ventas callejeras, 3) cabalgata, 4) reinas, 5) mujeres de Cali, 6) plaza de toros, 7) hacienda y caña, 8) guarapo, 9) espacios laborales (fábrica y oficina) y 10) baile. A diferencia de Oiga vea, donde las entrevistas son fundamentales, Cali: de película es básicamente un documental de observación. El cortometraje empieza con la voz superpuesta de un narrador, que oímos inmediatamente después de unas campanadas: "En Cali pusieron las tres cruces para que no entrara el diablo, pero el diablo estaba adentro y no ha podido salir". A partir de ahí la película busca transmitir la atmósfera de una ciudad poseída por el diablo: se trata de un diablo más bufonesco que malvado.

Cali: de película fue financiada por la Industria Licorera del Valle del Cauca y buscaba documentar la Feria de Cali. Aquí tenemos el reto de los cineastas: ¿cómo hacer una película que satisfaga a la institución que la financió sin que se convierta en una película publicitaria o en una oda a la ciudad de Cali y a su feria? Para responder a este reto se construyó una mirada crítica pero humorística, casi cariñosa y empática, que cobra diversas modulaciones de acuerdo a lo filmado. En el caso de "lo popular", se muestra su vitalidad: no en vano se empieza con el diablo, y se continúa con los pregones callejeros de los vendedores ambulantes. Las reinas de belleza, la cabalgata por la ciudad y la corrida de toros se hacen visibles de una for-

4 Disponible en: http://vimeo.com/94448658 
ma más crítica, en la cual la ironía y la sátira se transforman en un arma de cuestionamiento y de relativización.

Al igual que en Oiga vea, el contrapunto entre imágenes y sonidos es fundamental. Los planos se vinculan de una forma ágil y precisa, acorde con los eventos festivos que vemos. La banda de sonido en ocasiones acompaña las imágenes en movimiento y en otras opera como un comentario satírico, que resalta el carácter problemático de un acontecimiento o situación. Es posible mencionar tres secuencias en las cuales la sátira cobra especial relevancia. La primera de ellas es la cabalgata, en la cual se ven algunos jinetes borrachos a punto de caerse y a otros disfrazados de indígenas mientras se escucha una composición musical propia de un spaghetti western. Le sigue un espectáculo callejero protagonizado por un hombre y un caballo amaestrado, y luego aparece el diablo, primero bajo la figura de un hombre disfrazado, luego bajo la de un niño. Posteriormente el espectador es expuesto a una secuencia conformada por imágenes diversas cuyo punto de unión son las reinas de belleza. Los primeros planos de esta secuencia nos muestran a una reina desafiar el peligro al modelar, saludar y saltar sobre un trampolín en una piscina, todo ello con una música vagamente oriental; luego aparecen varias reinas más bajándose de carros y de carrozas, mientras se escuchan los comentarios fuera de campo de varias mujeres que hablan sobre las peripecias que deben hacer para evitar que se les caigan las coronas o sufrir otros percances.

El carácter observacional del documental es relevante aquí: la casi total ausencia de comentarios superpuestos por parte de un narrador y de entrevistas crea una obra abierta en la cual el espectador se ve confrontado con unas imágenes que distan de ser puras y objetivas, en tanto responden a una clara subjetividad a la hora de ser rodadas y montadas, pero que al tiempo dejan un espacio abierto a la reflexión. Como se ha planteado, el elemento central a la hora de direccionar el sentido está dado por el contrapunto musical y, en menor medida, por las voces fuera de campo del público asistente a los eventos de la feria. Ambos parecen relativizar el glamour y la distinción de los eventos protagonizados por los sectores sociales privilegiados. 
Esta relativización será más fuerte en la secuencia de la corrida de toros, que comienza con una cuenta regresiva construida a través del montaje de los burladeros numerados, para continuar con el desarrollo de una parte de la corrida de forma acelerada. Si la cámara lenta ha sido tradicionalmente una estrategia que busca contribuir, aumentar o crear el carácter "artístico" de los acontecimientos filmados, es posible preguntarse si la aceleración de las imágenes no sería una táctica para desvirtuar este carácter en la tauromaquia. Retomando la velocidad normal de la filmación, y entre planos de un torero corneado, del público aplaudiendo y de un toro siendo sacrificado, todo esto bajo "música taurina", se llega a un punto en donde se hace visible el "fuera de campo" del espectáculo, es decir que pasan literalmente a campo los cadáveres de dos toros y un caballo - con los vientres abiertos y las vísceras a la vista - que han sido depositados en la zona de la plaza vedada al público. Sería temerario afirmar que hay aquí una crítica antitaurina frontal, porque de nuevo se trata de unos planos muy abiertos a la interpretación, pero no deja de ser cierto que se muestra una serie de imágenes que aun el público habitual de las corridas no está acostumbrado a observar.

Si se sigue a Siegfried Kracauer (1996), es posible plantear que en esta escena hacen presencia sucesiva las dos funciones principales del cine: en un primer momento, la función de registro - más específicamente de registro del "movimiento objetivo"-, la corrida es representada a través del registro mecánico del flujo de la vida; el acontecimiento se vuelve a hacer presente en tanto el movimiento es siempre actual. Inmediatamente después, la función de registro es relevada por la función de revelación, que para Kracauer es ante todo la revelación de lo generalmente invisible, ya sea porque el hábito y el prejuicio impiden verlo, o porque abruma la conciencia humana de tal forma que esta se nubla ante su presencia. Los ejemplos dados por el autor son la violencia y la muerte descarnada. El espectador así confrontado debe elaborar este registro y esta revelación.

Luego de esta secuencia, la película continúa con tres secuencias más, todas muy cortas. En la primera se muestran los cultivos de caña de azúcar, lo cual sirve para justificar la necesaria — dada la financiación — secuencia de la Industria Licorera del Valle; no obstante el rodeo por las plantaciones, 
esta visita a la fábrica sigue viéndose como un poco forzada. A continuación se tiene un fragmento construido como un collage de planos de una industria metalúrgica y una oficina al final de una tarde laboral. Después del trabajo, y en plena Feria de Cali, llegan la fiesta y el baile. A diferencia de las otras actividades lúdicas vinculadas a este evento, como el reinado de belleza, la cabalgata y la corrida de toros, el baile recibe un tratamiento descriptivo, en el cual la sátira no está presente.

En una entrevista en la cual era interrogado sobre el cortometraje de ficción Asunción (Navarro, 1977, p. 35), Ospina comentaba que la salsa fue durante un buen tiempo una música con un carácter marcadamente popular. En Cali: de película, bailar salsa parece tomar el lugar que tenía la palabra en Oiga vea, aunque en esta también está presente el baile. Se trata, entonces, de la expresión de "lo popular" ya no en sus propias palabras sino en sus propios pasos - gestos y movimientos-, los cuales ayudan a conformar una comunidad posible, una comunidad de cuerpos que hacen. Si en Oiga vea las posiciones oficial y popular-marginal eran problematizadas, en Cali: de película el núcleo de la reflexión audiovisual se encuentra en cómo crear cultura y comunidad desde el vientre de la bestia o, mejor aún, desde el vientre de la fiesta, de una fiesta oficial. El cortometraje documenta entonces una serie de tácticas que, sin un lugar propio, y más exactamente sobre los lugares propios de la institucionalidad —el espacio público o las festividades oficiales-, desvía los sentidos y las prácticas convencionales a través del despliegue de las argucias de los vendedores ambulantes o de las artimañas dancísticas de los bailarines de salsa. No en vano De Certeau definía la cultura como "la proliferación de las invenciones en los espacios de la constricción” (2007, p. 17).

Lo interesante es que los cineastas también despliegan sus argucias y logran forzar los límites del cine oficial al tiempo que los caleños logran forzar las constricciones del ocio administrado en las sociedades modernas. La integración del ritmo construido por el montaje cinematográfico con el ritmo de la fiesta hace posible un torrente de sentido que emociona y cuestiona al espectador (Martínez Pardo, 1978, pp. 351-352). Por supuesto, esta emoción y este cuestionamiento variarán conforme a la posición 
sociopolítica del espectador. ¿Qué habrá pensado el público mayoritario que disfrutaba de la feria? ¿De qué maneras se habrá sentido interpelado un imaginario militante que consideraba a priori las ferias oficiales como manifestaciones opiáceas? Cali: de película construye unas imágenes pese a todo políticas. Su carácter político reside en el reconocimiento de la producción de los consumidores; los caleños del común ponen justamente en común la fiesta, la vuelven una plataforma de creación de comunidad y de invención cotidiana de formas de vincularse. Regresando a Rancière, es posible señalar que "para los dominados [es decir, para el común de los sujetos] la cuestión no ha sido nunca tomar conciencia de los mecanismos de dominación, sino hacerse un cuerpo consagrado a otra cosa que no sea la dominación" (2010, p. 64). ¿Quién vive su goce como alienación?, parecen preguntarse los cineastas.

\section{"No, pues, que abra el ojo que lo están filmando"}

Agarrando pueblo fue filmada en 16 milímetros en Bogotá y en Cali en 1977 y estrenada en 1978. Su título proviene de una expresión usual en el departamento del Valle del Cauca, que significa engañar: "En la película el título tiene un doble significado: el coloquial y el de agarrar miseria filmada metiéndola en una lata para exportarla" (Alvarado Tenorio \& Toro, 2011, p. 31). Inicialmente la película se concibió como parte de un proyecto mayor denominado tentativamente "El corazón del cine", inspirado libremente en un guion de Vladímir Mayakovski (Pérez \& Gómez, 2011, p. 210). El mediometraje se compone de cuatro segmentos: 1) búsqueda y filmación de la miseria en Cali y Bogotá; 2) planificación en una habitación de hotel del rodaje de la última escena del documental ficticio ¿El futuro para quién?; 3 ) intento frustrado de rodaje, y 4) entrevista a Luis Alfonso Londoño por parte de Ospina y Mayolo.

Agarrando pueblo disolvía las fronteras, en ese entonces más rígidas, entre documental y ficción, y simultáneamente realizaba un ejercicio de reflexión metafílmica de gran densidad y perspicacia dentro del contexto del "sobreprecio", término que hace referencia a un periodo particular de la producción cinematográfica colombiana (aproximadamente entre 1972 y

5 Disponible en: http://vimeo.com/39426604 
1978), en el cual se realizó una cantidad relativamente importante de cortometrajes en 35 milímetros a través de la financiación lograda por el cobro de un porcentaje del valor de las entradas a cine que era reinvertido en la producción cinematográfica nacional bajo ciertas condiciones (Martínez Pardo, 1978). En palabras de Luis Ospina, esta política de fomento favoreció a las personas del medio cinematográfico, pero desembocó en una fórmula: "salir a filmar indios, gamines, locos, mendigos, etc., y ponerles un texto en off a esas imágenes. Eso después se vende en Europa como un plato exótico" (Navarro, 1977, p. 36). Esto le hizo mucho daño a la relación del cine colombiano con el público.

Si retornamos a la idea del neocolonialismo cultural y a la centralidad de la discusión sobre el desarrollo en el documental latinoamericano de la década de los setenta, Agarrando pueblo se presenta en un primer momento como el making of de un documental miserabilista, en el cual se acentúan las consecuencias del "subdesarrollo" en la población colombiana. En un segundo momento, el miserabilismo es revertido y el acento recae ya no sobre las miserias reales sino sobre la miseria del registro cinematográfico de lo real. La autorreflexividad de la película, sumada a la constante exhibición en los teatros de cortometrajes que agarraban "indios", gamines, locos y mendigos para mostrárselos de forma estereotipada y condescendiente al "gran público", permitió unir crítica sociopolítica y crítica al medio cinematográfico.

Esta unión se realizó a través de diversas estrategias audiovisuales. Una de ellas es la escisión en la primera y tercera secuencia, entre lo filmado a color por los personajes que hacen parte del equipo técnico de ¿El futuro para quién? y el making of ya señalado, en blanco y negro. Esta división permite mostrar los contrastes maniqueos utilizados por pornomiseria, puesto que en ¿El futuro para quién? se contraponen los grandes y modernos edificios del centro de Bogotá con la miseria de unos niños que se lanzan a nadar desnudos en la fuente de La Rebeca por unas cuantas monedas que les tira el personaje interpretado por Carlos Mayolo. Es posible que la crítica a los contrastes obvios entre elementos que representaban el desarrollo con aquellos que representaban el subdesarrollo 
fuera en parte una autocrítica, ya que están presentes constantemente en Oiga vea, aunque de una forma burlesca, lo cual logra construir cierto distanciamiento reflexivo.

Otra estrategia es la puesta en abismo al final de la tercera secuencia, cuando el personaje interpretado por Luis Alfonso Londoño, mirando a la cámara, pregunta — $i$ los directores?, ¿a los espectadores? - “¿Quedo bien?”, luego de lo cual continúa la entrevista que le realizan a Londoño los dos directores. Si la miseria había servido al cine marginal como objeto de análisis y de denuncia, su banalización a través del denominado cine de sobreprecio había acabado con ese potencial, a lo cual se sumaba la creación de una relación conformista con este tipo de imágenes por parte de un público cada vez más habituado a ellas, lo cual retaba los procedimientos tradicionales del cine marginal. Se trataba de la disolución del pueblo, ya no por su subexposición sino por su sobreexposición. Para Georges Didi-Huberman:

Los pueblos están expuestos a desaparecer porque están -fenómeno hoy muy flagrante, intolerablemente triunfante en su equivocidad misma- subexpuestos a la sombra de sus puestas bajo la censura 0 , a lo mejor, pero con un resultado equivalente, sobreexpuestos a la luz de sus puestas en espectáculo. La subexposición nos priva sencillamente de los medios de ver aquello de lo que podría tratarse [...]. Pero la sobreexposición no es mucho mejor: demasiada luz ciega. Los pueblos expuestos a la reiteración estereotipada de las imágenes son también pueblos expuestos a desaparecer (2014, p. 14).

La pornomiseria contra la cual reaccionan Mayolo y Ospina establece unas relaciones aparentemente transparentes entre las imágenes y las palabras: ambas quedan reducidas a estereotipos. Sin embargo, también hay otros peligros: el mesianismo de izquierda, mediante el cual algunos cineastas toman el lugar del pueblo para hacerlo hablar con palabras o con movimientos que no les pertenecen, o la melancolía que observa la barbarie que trae consigo el desarrollo sin atreverse a realizar una labor de recomposición a partir de los jirones y los harapos, tal y como le aconteció a Pier Paolo Pasolini, quien luego de celebrar la vida del "pueblo" en la trilogía conformada por El Decamerón, Los cuentos de Canterbury y Las mil y una noches, decre- 
tó la muerte de las luciérnagas, es decir, la desaparición del "pueblo" ante el neofascismo de la década de los setenta (Didi-Huberman, 2012, p. 22).

La entrevista a Luis Alfonso Londoño en la última secuencia nos deja claro que en la Colombia de la década de los setenta la sobreexposición es un riesgo ante la cantidad de vampiros de la miseria que rondan en cualquier ciudad. ${ }^{6}$ Pero la misma entrevista hace evidente la necesidad de tratar de conocer a los sujetos y de hacerlo desde el punto de vista de su potencial de desalienación, como lo expresó Mayolo en entrevista con Alberto Navarro (1978, p. 79). Ese potencial solo se construye en la medida en que la película se constituye como un encuentro con los otros. En Agarrando pueblo observamos a los marginados, pero también los escuchamos, su voz nos confronta y es imposible ignorar la opinión que tienen sobre la agarradera de pueblo, como lo plantea Luis Alfonso Londoño cuando es entrevistado: "No, pues que ... abra el ojo que lo están filmando. Uno se para por ahí $y$ eso es preciso que le tienen un lente o una cámara potente $\mathrm{o} . .$. le están robando una fotografía o... alguien está consiguiendo con uno sin uno darse cuenta, ¿no?”.

Para Ospina y Mayolo, se trataba de que los espectadores elaboraran a partir de sus experiencias y de su diálogo con la película una "consciencia visceral" del colonialismo cultural, que los confrontara de una forma que no era posible a través de las proclamas antiimperialistas. ¿Qué mejor forma de demostrar que los "americanos" no son los únicos que pueden hacer cine que haciéndolo, y haciéndolo al lado de quienes tradicionalmente han sido agarrados? Películas como Oiga vea y Agarrando pueblo fueron en buena medida realizadas con las personas del barrio El Guabal. La segunda, en particular, según Mayolo, contó con cerca de 100 "asistentes de dirección" informales y voluntarios que recordaban los diálogos de los personajes y "validaban" o no las escenas con sus risas y con sus comentarios (Navarro, 1978, p. 74). Esta participación colectiva fue seguramente más efectiva que cualquier proclama sobre un cine propio para demostrar que "nosotros los

6 La película fue titulada en inglés The Vampires of Poverty. Además, el director ficticio interpretado por Carlos Mayolo señala, luego de filmar a una mujer indigente y a su pequeña hija: "Creo que quedamos como unos vampiros, oís, quedamos como unos hijueputas vampiros que nos bajamos ahí...”. 
colombianos también podemos poseer ese don de movernos ante una cámara de cine, aunque nos falte cultura ¿Por qué no?”, como señaló Luis Alfonso Londoño en la entrevista del último segmento.

\section{"El corolario es casi inevitable"}

Como se ha planteado, los tres documentales construyen, ante todo, puntos de vista y puntos de escucha que en muchas ocasiones son análogos, mas no idénticos, a los del "pueblo". Esta analogía ha partido, en buena medida, de un acercamiento a "lo popular" que no rechaza sus formas de expresarse, de sentir, de pensar y de divertirse, como lo hacían desde una posición apocalíptica muchos artistas e intelectuales, tanto de "derecha" como de "izquierda". Si el "pueblo" sobrevive gracias a la salsa, el humor negro, la sátira y la burla (Navarro, 1977, p. 35), los cineastas fundan su cine en una estrategia análoga; en palabras de Ospina, él y Mayolo hacen de la risa su método de trabajo: "empieza en la risa, luego se vuelve una operación de trabajo que trata de ubicar esa risa, o sea, darnos cuenta porqué nos da risa. Nosotros siempre empezamos a trabajar cuando algo se nos desmitifica, la mejor manera de evidenciar eso es burlándonos" (Valverde, 1978, p. 207). Se está lejos del carácter regenerador de la risa medieval y renacentista tal y como la interpretó Bajtín (1995), pero no por ello deja de operar su potencial liberador, que abre una pequeña puerta a la carnavalización del mundo, entendida como la liberación de la seriedad oficial con el fin de abrir la posibilidad de una nueva seriedad parcialmente libre y lucida, presente en la sonrisa de la mujer al final de Oiga vea, en el baile de Cali: de película, en las palabras y en el gesto obsceno de Luis Alfonso Londoño en Agarrando pueblo.

Estas tres películas son pues artefactos potencialmente desmitificadores, que, sin embargo, no realizan su labor a través de proclamas o mensajes claros, sino que proponen una gama de sentidos elaborados cinematográficamente, es decir, a través de las imágenes en movimiento, los sonidos y su interacción, demostrando, como lo planteó Martínez Pardo (1978, p. 289), que la riqueza semántica no es contraria a la comprensión popular del cine ni al cine político en sí mismo.

Dentro de la elaboración de un método de la risa y de una producción de sentido virtualmente abierta, el encuentro con los otros es de nue- 
vo fundamental y se presenta en varios momentos; durante el rodaje, hace posible la irrupción de lo aleatorio y lo indeterminado. El mejor ejemplo de esta irrupción es seguramente la escena de La Rebeca, en la cual la participación del hombre que critica agresivamente la filmación de los niños lanzándose a la fuente por unas monedas responde a un malestar "real" de esta persona (Navarro, 1978, pp. 73-74). Además, ver la película con el público abre caminos de comprensión para los cineastas sobre su propia obra. Si la visión conjunta es previa al montaje final, servirá de base para su culminación, pero si es posterior permitirá apreciarla de otra forma. Mayolo contaba al respecto: "Yo no sabía que Agarrando pueblo era una comedia popular sobre la crítica de cine; creía que era una película sobre el cine. Pero, al verla con el público, me di cuenta de que era una comedia que hacía reír, y desmitificaba una cantidad de cosas serias, que es lo que debe lograr la comedia" (Navarro, 1978, p. 76). Esta experiencia es útil además a la hora de buscar formas dramáticas no convencionales que apuesten decididamente por la comprensión y el goce de los espectadores populares. En este sentido, es el público quien completa la película, e incluso se podría afirmar que sin la participación de este la película simplemente no existe.

El encuentro entre los filmes y su público no es, por supuesto, un encuentro fácil y determinado de antemano, por más que las películas se hayan construido con su colaboración. El cine abre un espacio que puede ser aprovechado de diversas formas, o incluso desaprovechado; se trata de un encuentro con los espectadores populares que está abierto. Allí, paradójicamente reside su eficacia estética, que no es más que “[ ... ] la eficacia de la separación misma, de la discontinuidad entre las formas sensibles de la producción artística y las formas sensibles a través de las cuales ésta se ve apropiada por espectadores, lectores y oyentes. La eficacia estética es la eficacia de una distancia y de una neutralización" (Rancière, 2010, p. 58). Es imposible pues determinar los efectos de la relación entre las intenciones de los cineastas, las obras como formas sensibles, la sensibilidad de los espectadores y las modalidades de recepción en común y creadoras de lo común.

El cine crítico, descolonizador, implica una apertura al encuentro, al vínculo, al disenso y a las múltiples formas de reparto de lo sensible, un 
reconocimiento de la capacidad de los sujetos-cualquiera por producir sentido, sin ir de la mano de una voz superpuesta o alguna otra estrategia retórica que guíe autoritariamente a los espectadores, reducidos a infantes. A partir de Jacques Rancière (2010, p. 79), es posible plantear que el cine crítico y descolonizador es una práctica que no apunta a eliminar la pasividad del espectador, sino a repensar su actividad. También es posible, y tal vez sea necesario, afirmar que las películas rodadas por Carlos Mayolo y Luis Ospina hacen parte de ese cine.

\section{Filmografía}

Ospina L. \& Mayolo, C. (Dirs.) (1972). Oiga vea [cortometraje]. Luis Ospina, Carlos Mayolo y Ciudad Solar.

Ospina L. \& Mayolo, C. (Dirs.) (1973). Cali: de película [cortometraje]. Cine al Ojo y Cinesistema.

Ospina L. \& Mayolo, C. (Dirs.) (1978). Agarrando pueblo [cortometraje]. Sindicato de Artistas y Trabajadores Unidos para la Liberación Eterna.

\section{Bibliografía}

Alvarado Tenorio, H. \& Toro, H. (2011). Con Luis Ospina Agarrando pueblo desde París. Entrevista con Luis Ospina. S. Chavarro, R. Arbeláez \& L. Ospina (Eds.), Oiga / Vea: sonidos e imágenes de Luis Ospina (31-33). Cali: Universidad del Valle.

Bajtín, M. (1995). La cultura popular en la Edad Media y en el Renacimiento. El contexto de François Rabelais. Madrid: Alianza.

Caicedo, A. (1974). Oiga, vea. Ojo al cine, 1, 51-55.

De Certeau, M. (2007). La invención de lo cotidiano I. Artes de hacer. México: Universidad Iberoamericana e ITESO. 
Didi-Huberman, G. (2012). Supervivencia de las luciérnagas. Madrid: Abada.

Didi-Huberman, G. (2014). Pueblos expuestos, pueblos figurantes. Buenos Aires: Manantial.

González Martínez, K. (2014). Cali, ciudad abierta. Arte y cinefilia en los años setenta. Bogotá: Ministerio de Cultura.

Kracauer, S. (1996). Teoría del cine. La redención de la realidad física. Barcelona: Paidós.

León Frías, I. (2013). El nuevo cine latinoamericano de los años sesenta. Entre el mito político y la modernidad filmica. Lima: Universidad de Lima.

Martínez Pardo, H. (1978). Historia del cine colombiano. Bogotá: América Latina.

Navarro, A. (1977). Entrevista con Luis Ospina. Cinemateca, 1(1), 30-37.

Navarro, A. (1978). Entrevista con Carlos Mayolo. Cinemateca, 2(5), 70-82.

Nichols, B. (1997). La representación de la realidad. Cuestiones y conceptos sobre el documental. Barcelona: Paidós.

Ortega, M. L. \& Martín Morán, A. (2003). Imaginarios del desarrollo: un cruce de miradas entre las teorías del cambio social y el cine documental en América Latina. Secuencias. Revista de Historia del Cine, 18, 33-48.

Pérez, C. \& Gómez, S. (2011). Luis opina (de su obra). Entrevista con Luis Ospina. En S. Chavarro, R. Arbeláez \& L. Ospina (Eds.), Oiga / Vea: sonidos e imágenes de Luis Ospina (203-219). Cali: Universidad del Valle.

Rancière, J. (2010). El espectador emancipado. Buenos Aires: Manantial.

Valverde, U. (1978). Reportaje crítico al cine colombiano. Bogotá: Toronuevo. 